\title{
Carotid artery stenting, new devices and techniques for interventional cardiology and atrial fibrillation
}

In this issue of Anatolian Journal of Cardiology, in a scientific letter, Sticchi et al. from Italy suggest that in patients with COVID-19, diabetes seems to represent a significant risk factor in determining poor outcomes. However, further research is warranted to clarify the mechanisms of this interaction.

Floria et al. from Romania discuss the significance of incomplete right bundle branch block, a common electrocardiogram finding, and the measures that should be taken if it is present.

Köklü et al. from Turkey present their experiences and results of carotid artery stenting (CAS). Their research involves a multidisciplinary team approach, with analysis conducted by both neurologists and cardiologists. They claim that long-term results of CAS procedures performed jointly by a neurologist and a cardiologist in a high-volume single center using multidisciplinary evaluation have not been published before. I hope that these findings will contribute to this topic and serve as a reference.

Ray et al. from India discuss a small burr modified rotational atherectomy technique with scoring balloon angioplasty predilatation in moderately and severely calcified coronary lesions, suggesting that this is a safe and effective procedure with favorable clinical outcomes.

Malik et al. from Pakistan aimed to compare the safety profile of the PreludeSYNC DISTAL radial compression device (PSD; Merit Medical Systems, Inc., South Jordan, UT, USA) and the TR band radial compression device (Terumo Medical Corporation, Somerset, NJ, USA) for radial artery approach. It is the first study to compare these 2 hemostatic devices in terms of safety profile after coronary catheterization procedures.

Bozer et al. from Turkey investigated an interesting association between blood pressure (BP) and sleep in "Blood pressure, autonomic stress, and inflammatory markers during sleep deprivation and recovery in healthy men." Their study highlights the importance of sleep in regulating BP.

Sun et al. from China collected 9 left atrial appendage tissues from 3 patients with paroxymal atrial fibrillation (ParoAF), 3 patients with persistent AF (PersAF), and 3 donors. They investigated the functions of messenger RNA, long noncoding RNA, and circular RNA on patients with ParoAF and those with PersAF. The results are worth looking at.

In another study from China, Cao et al. investigated the potential microRNAs having diagnostic value in AF. They searched the public Gene Expression Omnibus database and found valuable data.

Bayram et al. from Turkey evaluated the relationships between functional mitral regurgitation (FMR) and pulmonary hypertension in patients for heart transplantation according to the updated definition of FMR. The results show that severe FMR is still a serious factor for pulmonary hemodynamics.

In addition, informative and interesting case reports, letters, and e-pages are included.

I hope that this issue of our journal will be appreciated by our readers.

\author{
Prof. Dr. Çetin Erol \\ Editor-in-Chief \\ Ankara-Turkey
}

Address for Correspondence: Prof. Dr. Çetin Erol, Ankara Üniversitesi Tıp Fakültesi, İbn-i Sina Hastanesi, Kardiyoloji Anabilim Dalı, Ankara-Türkiye

Phone: +90 3123103333 /27 79 E-mail: ctnerol@yahoo.com

(C) Copyright 2021 by Turkish Society of Cardiology - Available online at www.anatoljcardiol.com

DOI:10.5152/AnatolJCardiol.2021.6 